Katja Levy* and Anja Ketels

\title{
Outsourcing and Networking: Similar Trends in Local State-NPO Cooperation in Germany and China
}

https://doi.org/10.1515/npf-2020-0005

Received January 24, 2020; accepted November 18, 2020

Abstract: This paper presents results of a German-Chinese comparative research project on the provision of services by non-profit organizations (NPOs) in the field of migration. It argues that NPOs and local governments deploy similar strategies in their joint attempt to tackle social problems, regardless of their political backgrounds. From a top-down perspective German and Chinese local governments show similar outsourcing modes, while from a bottom-up perspective NPOs show similar practices of network governance.

Keywords: China, nonprofit, state-nonprofit relations, migration, Germany

\section{Introduction}

Under the influence of New Public Management, cooperation between non-profit organisations (NPOs) and local governments has become a crucial part of modern governance $^{1}$ (Salamon 1995). Theories of the welfare state have often based

1 We understand governance in its "new" sense, namely "in that it focuses less on the state and its institutions and more on social practices and activities" (Bevir 2012, 1). As Salamon explains: “"new governance' [...] shifts the attention from hierarchic agencies to organizational networks. The defining characteristic of many of the most widely used and most rapidly expanding tools [...] is their indirect character, their establishment of interdependencies between public agencies and a host of third-party actors" (Salamon 2011, 1628). He further clarifies: "rather than seeing such collaboration as an aberration or a violation of appropriate administrative practice, moreover, the 'new governance' views it as a desirable byproduct of the important complementarities that exist among the sectors, complementarities that can be built upon to help solve public problems" (Salamon 2011, 1633).

*Corresponding author: Katja Levy, Manchester China Institute, The University of Manchester, School of Social Sciences, Manchester, UK, E-mail: katja.levy@manchester.ac.uk. https://orcid. org/0000-0002-9186-5792

Anja Ketels, Graduate School of Politics, Institute of Political Science, University of Münster, Münster, Germany, E-mail: a.ketels@fu-berlin.de 
explanations for NPO involvement in governance processes on some type of failure whereby local governments cannot provide sufficient social services which in turn induces social actors to step in and fill the gaps (see Salamon 1987, 33-36). Salamon (1987) took this discussion further and introduced a theory of voluntary failure to explain the importance of NPO-government cooperation. According to this theory, the government mobilises and supports the non-profit sector for participation in governance processes. NPOs support government provision of social services, while the government compensates for NPO shortcomings such as limited resources and inadequate distribution thereof (Salamon 1987, 36-42). In both Germany and China, this development and the associated debate have recently gained new momentum in response to the challenges of providing social services to migrants. At the peak of the current influx of refugees into Germany in 2015, approximately 890,000 asylum seekers ${ }^{2}$ entered the country in one year and strained the capacities of local administrations (see Altrock and Kunze 2016). Civil society actors responded by developing new programs and showing high potential for engagement and innovation. In China, affluent cities face similar challenges in response to huge numbers of migrant workers arriving from poor rural areas (see Cai and Liu 2015). In 2018, a total of around 288 million migrant workers were counted in the country. ${ }^{3}$ Local governments must develop new means of providing social services and integration opportunities for the new populations in their cities. ${ }^{4}$ Administrations in both Germany and China are searching for solutions to these new challenges, and in both countries civil society is stepping in and playing

2 Press release from the Federal Ministry of the Interior, 30 Sept. 2016, available at http://www. bmi.bund.de/SharedDocs/Pressemitteilungen/DE/2016/09/asylsuchende-2015.html (last accessed August 16, 2019).

3 National Bureau of Statistics of the Chinese government, 29 April 2019, available at http://www. stats.gov.cn/tjsj/zxfb/201904/t20190429_1662268.html (last accessed August 16, 2019).

4 In both Germany and China, the responsibility for providing social services to migrants lies with the local government. A working paper summarized this similarity as follows: "In Germany, the local government, i.e. the specific municipality and/or federal state, is in principle the first provider of social services to migrants. The municipality (Kommune) is the third administrative level in the hierarchy, below the federal government (Bund) and the federal states (Bundesländer). Municipalities, in turn, include various local administrative and territorial structures such as communities, districts (Kreise), cities associated with districts (Kreisstädte) and independent cities (kreisfreie Städte) (Szeili und Zimmer 2017, 2f.). [...] In China, the term "local government” refers to all levels below the central government, namely the provinces, prefectures, counties and villages (Ma, Fan and Shan 2017, 1). Local governments' social service provision for migrants is still very limited due to the household registration system. However, they do bear the responsibility of providing social services in their jurisdiction” (Levy 2020,7). In our analysis, we primarily refer to the administrative levels of the four sample cities: Guangzhou and Hangzhou both have the status of prefecture-level cities that are only subordinate to the province and the central government. Berlin is a city-state, i.e. a city that simultaneously has the federal status; and in Cologne, the unit 
an increasingly important role in governance processes (see Freise and Zimmer 2019a, 2019b; Hasmath and Hsu 2015).

Based on the results of a three-year German-Chinese comparative research project, this article examines modes of state-society cooperation. Taking social services offered by societal actors to migrants in two Chinese and two German cities as case studies, we identify and analyse characteristics and underlying rationales of cooperation between local governments and NPOs.

Our decision to select cases in the two countries China and Germany and in the particular area of service provision for migrants requires an explanation. We chose the two countries because they are obviously very different. These clear differences in terms of political system, culture, history, geography and economic system mean that similar findings regarding the modes of cooperation are more significant than they would be for two more similar countries. ${ }^{5}$ In addition, resulting similarities in the governance processes cannot be attributed to similarities of the political system, culture, history, geography and economic system exactly because of these differences. We chose services for migrants, because the influx of migrants coming to the cities and demanding services and integration posed similar challenges to the local governments in both countries in the period studied (2016-2019). As mentioned above, the burden of providing social services lies on the shoulders of these local governments, and they seek to share this responsibility with social organisations that often act as more or less equal partners who contribute their knowledge, skills and human resources to varying forms of cooperation.

The results of our qualitative field research in the two countries indicate similar cooperative trends. From a top-down perspective German and Chinese local governments show similar outsourcing modes, while from a bottom-up perspective NPOs show similar practices of network governance albeit in different settings and with different power relations. We argue that NPOs and local governments deploy similar strategies in their joint attempt to tackle social problems, regardless of their political backgrounds. This research is based on

of analysis is the municipal level, which is however influenced by the federal state of North-Rhine Westphalia.

5 Less for this article, but for the larger LoGoSO project it is also interesting to see that, at different points of time, the two countries have had similar experiences. Both countries have traditionally emphasized the central role of the family in providing social services, and their early ideas on social policy revolved around protecting workers, and later developed forms of corporatist statesocial organisational relations. These developments have more recently been modified by neoliberal trends in public administration and the growing importance of commercial service providers.s 
first-hand observations on how social organisations provide services for migrants in Germany and China. By analysing cooperation modes pursued by NPOs and the state, this research contributes to the broader political science issue of governance.

In recent years, the question of how to integrate migrants has posed an exceptional challenge to local governments in China and Germany. The two countries have very different histories of migration. China has had relatively little immigration from foreigners but a brief and intense phase of internal migration, while Germany has a long history of immigrants from foreign countries with many fluctuations over past centuries (Ketels 2019, 7). This study focuses on recent migration trends in the two countries. China has seen intensified and more permanent internal migration over recent years. Huge numbers of people have moved from poor rural regions to affluent cities to improve their living conditions. The Chinese system does not recognise these migrants as full residents of their new destinations but rather considers them a floating population and refers to persons who stay in one location for only a limited amount of time. This floating population is usually not eligible for the household registration (hukou) at their destination which enables access to social services. Migrant workers moving to the Chinese industrial centres in search of better economic conditions for their families are the largest group within the floating population (Levy 2020, 2-4).

In Germany, the recent influx of large numbers of refugees from war-torn countries, such as Syria, Iran and Afghanistan, is the focus of this study. Since 2015, what is called the "refugee crisis" has dominated public debate, challenged the capacities of local administrations and triggered engagement by NPOs. Although there are different legal forms of asylum in Germany, because they entail similar rights for the persons in question all of these groups will be referred to as "refugees" in this paper. Most refugees are expected to stay in Germany for long periods of time, which makes their access to social services and integration a longterm political goal (Ketels 2019, 8; Levy 2020, 2-4).

The challenges involved in providing social services to the floating population in China and to refugees in Germany are similar in the sense that the migrants do not have full access to the regular social systems and that local administrations lack the resources and expertise to develop adequate solutions. In both countries, NPOs have responded to this challenge and showed exceptional readiness to develop assistance systems for migrants. Local administrations benefit from the NPOs' efforts and expertise and readily establish cooperation with them. Migration therefore provides an excellent policy field to explore modes of NPO-state cooperation. 
The remaining parts of this article are structured as follows: The literature review in Section 2 summarises previous research on state-NPO cooperation in western, i.e. North American and European, societies and in China. We then introduce our data collection and analysis methods in Section 3. In Section 4 we develop the theoretical framework of outsourcing for the top-down perspective and networking for the bottom-up perspective of the analysis, which we then apply in Section 5 to the qualitative content of 19 cases of state-NPO cooperation. The concluding section summarises and discusses our results.

\section{State of the Art: State-NPO Cooperation Structures in China and Germany}

State-NPO cooperative relationships in China and in Germany come from very different backgrounds and contexts. In China, the authoritarian system and the Communist Party's exclusive claim to power determine practically every development, whereas Germany traditionally depends on a corporatist power-sharing system with the non-profit sector as the backbone of the welfare state. However, the two systems face similar challenges in providing social services, and current discussions on best practices in this field show parallels. Against the background of NPM, ${ }^{6}$ the governments of both countries have developed ways of cooperating with NPOs to make use of the latter's productivity and expertise in providing social services.

Western research projects have taken several different approaches in explaining these cooperative relationships. Zimmer emphasises the markedly multifunctional nature of NPOs which makes them open to different types of cooperation, including with the state (Zimmer 2010, 201). Najam (2000) identifies four different possibilities for state-NPO cooperation based on institutional interests and preferences for policy ends and means, i.e. cooperative, confrontational, complementary or co-optative. Young (2000) found that complementary, supplementary and adversarial relations between the state and non-profit sectors exist in different countries, but vary over time and relative dominance. For Salamon (1987), efficiency and effectiveness are the major drivers for government/

6 New Public Management (NPM) is an approach to making public services more market-based rather than hierarchically organized. It first developed in the UK and Australia during the 1980s and soon gained popularity all over the world. Christopher Hood summarizes the main ideas of NPM as follows: "Hands-on professional management in the public sector; explicit standards and measures of performance; greater emphasis on output controls; shift to a disaggregation of units in the public sector; stress on private-sector styles of management practice; stress on greater discipline and parsimony in resource use” (Hood 1991, 4f). 
third-sector partnerships (Zimmer 2010, 201). Finally, Salamon and Toepler combine "voluntary failure" and third-party government/new governance theory in their explanations for state and non-profit cooperation. Voluntary failure denotes the deficiencies of the NPOs themselves that combine with the deficiencies of the market and the government and therefore enhance cooperation. In their view, typical deficiencies of NPOs are philanthropic insufficiency, philanthropic particularism, philanthropic paternalism and philanthropic amateurism. New governance theory considers a broad range of government limitations with regard to solving social problems and complements the insights of NPM by emphasising not only internal management mechanisms in state bureaucracies but also the different instruments of state/non-profit cooperation. In particular, it seeks to utilise the special strengths of NPOs, such as their flexibility, their own institutional structures and their ability to tailor services to individual needs (Salamon and Toepler 2015, $2162 \mathrm{ff}$.).

As for China, the predominant (western) explanation for the close relationship between the state and NPOs was the theory of corporatism. Originally, corporatism was used to explain a state-society relationship in which interest representation was organised top-down. Schmitter defined corporatism as "a system of interest representation in which the constituent units are organized into a limited number of singular, compulsory, noncompetitive, hierarchically ordered and functionally differentiated categories, recognized or licensed (if not created) by the state and granted a deliberate representational monopoly within their respective categories in exchange for observing certain controls on their selection of leaders and articulation of demands and supports" (Schmitter 1974, 93 f.). Unger and Chan (1995) were among the first scholars to propose using this concept to explain the relationship between state and societal organisations in the People's Republic of China (PRC). In doing so, they emphasised that corporatism was applied as a way to organise societal sectors without direct state intervention. As they write: "within such corporatist framework, the state does not attempt to dominate directly. It leaves some degree of autonomy to the organizations within each of their respective spheres of operation. But to ensure that the compacts and agreements achieved at the top get implemented effectively, it demands that the organizations exercise some discipline and control over their own memberships" (Unger and Chan 1995, 30). The two scholars also distinguished social or liberal corporatism on the one hand, and authoritarian state corporatism on the other. While the former term is used for western democracies in describing how the "leaders of the peak association are beholden to their memberships, not the state, and the state is not directly in a position to dictate the terms of agreement between sectors" (Unger and Chan 1995, 31), the latter term is reserved for authoritarian regimes like China "where the weight of decision-making power lies very heavily on the side of the state" (Unger and Chan 1995, 31). They emphasise that " $[\mathrm{w}]$ hat both ends of this corporatist spectrum hold in 
common is the notion that organised consensus and cooperation are needed, in contrast to the divisive competition and conflict entailed by pluralist interest-group models of organization" (Unger and Chan 1995, 32). The focus of this theoretical approach is interest representation and political steering of certain societal sectors via representative organisations of these sectors.

Corporatist approaches had great explanatory value for the situation in China in the 1980s and 1990s when "government-organised non-governmental organisations" (GONGOs), i.e. large organisations initiated either by the state or the Communist Party, such as the China Children and Teenagers Fund, the Communist Youth League and the All-China Federation of Trade Unions, were used as “conveyor belts" to transport Party policies down to the people and people's grievances up to the political decision makers.

However, today we find that many service organisations are neither stateorganised nor consider interest representation to be their primary mission. In our sample, the Chinese organisations also generally take the legal form of social service organisation (社会服务机构 shehui fuwu jigou), which is not membershipbased and therefore cannot function as representative of a certain societal sector. Instead, they offer services as a type of profession or business, even though they have to be registered by the state and in most cases work closely together with the authorities. This is why new theoretical approaches have arisen in research on the third sector in recent years, which try to capture and explain this shift and complement or even replace the corporatist approach. Jessica Teets, for example, has added the concept of consultative authoritarianism to this China-related set of explanations for state-non-profit cooperation. She showed how recentralisation and tax reform in favour of the central government have forced local governments to consider NPOs as alternative public service providers. Increased dependence on NPOs has made the government reluctant to take violent and extra-legal actions against them (Teets 2014). Further recent approaches include that of Hildebrandt (2013), who explained the Chinese state-society relationship as a form of co-dependency. Levy and Pissler (2020) take a functional perspective and suggest viewing cooperation between the Chinese state and NPOs as a form of governance.

From a Chinese perspective, the country's economic and social development has required new development strategies for NPOs and more complex involvement by them in governance processes (Ma and Liao 2015). Jing (2015) shows that the Chinese government has responded to these new developments and challenges by intensifying its control strategies on the one hand and by starting to actively empower the development of NPOs on the other. In a similar vein, Kang and Heng $(2005,2008)$ apply their "system of graduated controls" to analyse the extent to which state control depends on a given organisation's scope, its capacity to challenge the state, and its value to public services. Wang and Kang (2018) summarise a tightened reconfiguration of policy and power that commenced in the 
wake of the 18th party congress in 2012 and accompanies the reorientation from purely state-centred, economically oriented policy to more diverse and sustainable development policy, which in turn encompasses an increasing involvement of NPOs in state structures (Wang and Kang 2018, 1). Over the course of this development, the system of government service purchasing (GSP) from NPOs has gained momentum and the Chinese government has emphasised "fully recognize the importance of GSP from social forces” (Wang and Snape 2018, 4).

In Germany, the neo-corporatist welfare state traditionally involves non-state actors in the provision of social services (Evers 2011). For decades, a limited number of umbrella organisations operated in close partnership with the government and enjoyed a privileged position in policy making and access to funding (Zimmer 2010). Since the early 1990s, this position has changed and gave way to a system in which NPOs must compete with for-profit social-service providers (Freise and Zimmer 2019a, 2019b, 14). Freise and Zimmer (2019a, 2019b) argue that a new assessment of the German welfare state and the role of civil society is needed as the traditional welfare mix is currently at a crossroad defined by changing actor constellations, new social problems and new political strategies (Freise and Zimmer 2019a, 2019b, 395).

In summary, both Germany and China have a tradition of corporatist stateNPO relations, which, however, gave way to more diversified and market-driven cooperation models. This article contributes to the larger discussion on statesociety cooperation, and more substantially to a more nuanced understanding of the characteristics and rationales of state and non-state actors in how they deliver social services in different societies and/or turn to outsourcing and network governance.

\section{Data and Methodology}

This paper aims to identify, analyse and compare models of cooperation between local governments and NPOs in both Germany and China. The two country teams each chose two sample cities in their country. ${ }^{7}$ In order to ensure comparability,

7 The sample cities were chosen to represent one of the largest cities in each country (Berlin, Guangzhou) and one medium-sized city (Cologne, Hangzhou) that function as economic hubs in their regions. All are immigrant cities with a well-established third sector. Berlin is the German capital and largest city in the country. As a city-state in the federal system, it enjoys relative freedom concerning policy development and implementation. Cologne, on the other hand, is subordinate to the state of North-Rhine Westphalia and bound to the guidelines and regulations dictated on the state level. Likewise, Guangzhou is relatively independent, and as one of the richest and largest cities in China enjoys the status of "model city" for developing a public 
the two teams selected cases of NPO-state cooperation in the four policy fields of education, employment, social assistance (including legal aid) and vulnerable groups, which are core areas of social services for migrants in both countries. In order to cross-check the results on the conditions that lead to the success or failure of cooperation, we also selected one case in each city that stakeholders considered a failure in this regard. ${ }^{8}$ The two research teams went into the field to collect data from July 2018 to April 2019. In each city we selected five cases following an organisational approach and in accordance with the following criteria:

- All cases are cooperative efforts between an NPO and the local government.

- All cases are programs/projects that focus on services for migrants.

- NPO size, age, migrant involvement in operations, funding source, competition, administrative level shall all vary. ${ }^{9}$

The German and Chinese research teams conducted interviews with managers, staff and volunteers of the NPOs as well as with local government representatives. The authors of this paper were involved in all phases of the research. Backed by desktop research and observations, the interviews lay the foundation for the extensive case studies.

For this paper we applied a secondary analysis of the 19 case study reports written by the two research teams based on their fieldwork. The aim is to identify characteristics and rationales of cooperation in the German and Chinese cases and find patterns for them across different societies. Based on existing research we tested earlier theories of state-NPO cooperation by deduction and complemented these insights by inductively identifying the rationales underlying these cooperative relationships. We argue that while the characteristics are similar in Germany and China, the rationales behind the application of certain modes of cooperation are different.

management system for migrants. Hangzhou is the capital and economic centre of Zhejiang province, but it develops and implements policy primarily in response to guidelines from provincial or national levels (Ketels 2019, 17). All four cities are strongly influenced by migration and turn to NPOs in seeking effective solutions for this challenge (Ketels 2019, 17-18, available at: https://refubium.fu-berlin.de/handle/fub188/17676).

8 In our cases, failure means that a desired NPO-state cooperation did not take place, was aborted, or did not achieve the desired outcomes. This does not necessarily mean that the NPO's project as such is a failure. Due to the difficulty of tracing cooperation that did not arise or no longer exists, the selection of failed cases turned out to be extremely difficult and in one city, Cologne, was ultimately unsuccessful.

9 See the Appendix of this paper for an overview of the basic characteristics of the 19 cases. 
In order to identify these characteristics, we used MAXQDA software to code the nineteen case-study reports along the categories that we developed based on the theoretical framework of third-party government and network governance (see Section 4). To identify the underlying rationales, we inductively developed the categories during the coding process. Transcriptions of the Chinese interviews and secondary literature were consulted when additional information was needed.

\section{Outsourcing and Networking Theory}

Since the early 1980s, third-sector research in western countries has concentrated increasingly on the relationships between governments and NPOs. The realisation that modern welfare states rely on joint efforts by governments and third-sector organisations gave rise to various perspectives on this partnership focussing on NPO roles in policy processes, NPO activities and the modes and/or effects of cooperation (Zimmer 2010). To analyse the state-NPO relationships in more depth, third-party government and network governance are concepts that successfully capture the complex relationships and operational work by the NPOs in both countries across all policy fields. By employing these two theories, we are able to examine the cooperative modes between NPOs and local governments from two sides: the third-party government concept offers a fruitful framework for analysing the top-down outsourcing mechanisms from government to NPOs, while the network governance approach sheds light on the bottom-up networking structures by NPOs that cooperate with government. This section of the paper provides an overview of these two theoretical approaches.

\subsection{Third-Party Government}

In response to the fact that NPO-state cooperation was still a largely overlooked topic, in the early 1980s Lester Salamon started to develop and explore the concept of "third-party government", which he summarised in his book Partners in Public Service: Government-Nonprofit Relations in the Modern Welfare State (Salamon 1995). He argues that a "lack of theory" was responsible for neglecting the growth and significance of the third sector in the United States. A new form of governance, which Salamon called "third-party government", had developed and required a theory that acknowledges government-NPO partnerships and thereby goes beyond theories of the welfare state and the voluntary sector (ibid., 15-16). Under "thirdparty government”, NPOs fulfill various governmental functions. Via different channels, the government transfers funds and responsibilities to NPOs which 
become crucial actors in delivering public services while at the same time derive large parts of their income from the government (ibid., 33-34). The theory of the welfare state obscures this development because it ascribes all authority for providing social services to the state alone. Likewise, theories of the voluntary sector such as "market failure/government failure" cannot do justice to effective state-NPO partnerships because they explain the existence of the non-profit sector solely as a substitute for shortcomings of the government and the market. These theories fail to explain regulated cooperation, government support for NPOs and joint efforts for effective public management, and therefore it was necessary to redo the theory (ibid., 38-40). Salamon points out that the voluntary sector, like the government and the market, also has some inherent limitations, such as limited resources, favouritism and/or a lack of professionalism (ibid., 44-45). Regarding these kinds of voluntary-sector and government failure, it becomes apparent that both the non-profit sector and the government can profit from a partner that can compensate for their respective limitations. Salamon argues that “the voluntary sector's weaknesses correspond well with government's strengths, and vice versa" (ibid., 48). A collaborative partnership in which one actor does not replace the other but in which government and NPOs join forces for effective public management would therefore be the most efficient solution. In other words, the modern welfare state “[...] is an elaborate system of 'third-party government' [...], in which government shares a substantial degree of its discretion over spending of public funds and the exercise of public authority with third-party implementers" (ibid., 41).

As a concept that accepts and formalises institutional pluralism, third-party government is similar to contracting. However, it is more complex and extends beyond contracting by not only including specified contracts for service delivery but possibly also entailing formalised tools such as loans or insurance that transfer service delivery to NPOs in more flexible ways. Moreover, under third-party government the government not only shares allocated funds with NPOs but also transfers decision-making authority on spending the funds and on public administration (Coston 1998, 369).

Our analysis in Section 5 shows that the outsourcing of services from local governments to NPOs both in Germany and China is characterised by many aspects of third-party government in different ways.

To identify the outsourcing characteristics by deductive means, we coded the case reports in our qualitative content analysis along five basic criteria for stateNPO cooperation in Salamon's third-party government framework:

1. Existence of formalised cooperation: collaboration that is formalised in some way and in which the NPO is officially recognised. 
2. Transfer of administrative responsibilities: cooperation in which the NPO assumes public administration responsibilities.

3. Complementary cooperative relationship: collaboration in which the functions and responsibilities of state and NPO complement each other by balancing their respective strengths and limitations.

4. Congruence of goals: cooperation which is based on congruent goals by the state and NPO regarding public administration.

5. Favourable power relation: cooperation in which the state has a power advantage but the NPO also has a certain degree of autonomy and/or participation in decision-making.

\subsection{Network Governance}

Most of the case reports in our sample show a high degree of networking on the part of the NPOs. Networks, or the embeddedness of (economic) actors, were described most prominently by Granovetter in explaining economic exchanges (Granovetter 1992). Network governance theory originally derived from the observation that many industries were increasingly using a form of coordination characterised by informal relationships rather than by bureaucratic structures within organisations and formal contractual relationships in order to coordinate complex production procedures or services in uncertain and competitive environments. Network governance is a field of research that has recently received increased scholarly attention, particularly from the "top down" perspective of governments networking with societal actors. Two examples of recently published and rather comprehensive works are Kapucu and $\mathrm{Hu}$ (2020) and Emerson and Nabatchi (2015). Kapucu and $\mathrm{Hu}$ offer a textbook on network governance, encompassing basic definitions, aspects of leadership, and also real-life applications of network governance. Emerson and Nabatchi published an equally comprehensive textbook on collaborative governance, illustrated by manifold case studies. These and other works on network governance and collaborative governance are approaches to analyse and understand the building of networks from the perspective of the government's governance - networks involving government actors/organs and societal actors.

The particular networks that we study in this article, however, are the "bottom up" networks, the networks that are formed by NPOs facing the challenge of cooperating with the local governments. These networks are formed primarily among societal organisations but might also include government agents or organs. In other words, they are NPO networks within network governance/collaborative governance in the sense of government organs collaborating with societal actors. 
For the purpose of analysing the particular needs and practices of this "bottom up"-side of network governance, we find the article of Jones et al. (1997) particularly enlightening. In their explanation of when network-type relationships are likely to occur and how they can help the organisations involved (businesses or NPOs) resolve their problems, Jones, Hesterly, and Borgatti (1997) integrated the concept of network governance and the theory of transaction cost economics. Based on this approach, Jones et al. redefined network governance as follows:

"Network governance involves a select, persistent, and structured set of autonomous firms (as well as nonprofit agencies) engaged in creating products or services based on implicit and open-ended contracts to adapt to environmental contingencies and to coordinate and safeguard exchanges. These contracts are socially-not legally-binding." (Jones, Hesterly, and Borgatti 1997, 914)

By "select" they mean that network members usually form a subset of an industry in which they engage in frequent exchanges. "Persistent" denotes the dynamic process of organising and reorganising the network by its members. This definition describes the network exchanges as "structured" in the sense that they are "neither random nor uniform but rather are patterned, reflecting a division of labor". Finally, "implicit and open contracts" indicate that exchanges are not governed by authority structures or legal contracts, but are formed in a process of adapting and coordinating exchanges that relies on "social coordination and control, such as occupational socialisation, collective sanctions and reputations". This does not exclude the existence of formal contracts among some members of the network as long as "these do not define the relations among all of the parties" (Jones, Hesterly, and Borgatti 1997, $914 \mathrm{ff}$.). In explaining why this form of governance is preferred by the organisations, Jones et al. use the basic ideas from transaction cost theory. They propose that organisations choose to engage in networks when environmental uncertainty demands adaption, the exchanges involve "unique equipment, processes, or knowledge developed by participants to complete exchanges, and the exchange is frequent, because frequent exchanges facilitate the transfer of tacit knowledge, facilitate embeddedness, and may provide cost efficiency" (Jones, Hesterly, and Borgatti 1997, 916).

Our analysis in Section 5 shows that the cooperation of NPOs with local governments both in Germany and China is characterised by different aspects of network governance.

To identify the existence and characteristics of network governance by deduction in the cooperative relationships between NPOs and local governments in our cases, we coded the case reports in our qualitative content analysis along the following four conditions proposed by Jones, Hesterly, and Borgatti (1997) as heuristic devices: 
- Demand uncertainty: for this research project involving non-profit actors, we slightly adapted the original uncertainty of (market) demand to an uncertainty of funding.

- Asset specificity, i.e. particular knowledge, skills or other assets are necessary to provide the required services.

- Task complexity, i.e. the service to be delivered involves a number of parties and subtasks that need special coordination.

- High exchange frequency, i.e. regular exchange in the networks over a lengthy span of time. ${ }^{10}$

In Section 5 we analyse the research reports.

\section{Analysis: State-NPO Cooperation in Migrant Service Provision in China and Germany}

This analysis comprises two parts: First, we analyse whether and how social services are outsourced in the two countries. Using the criteria of Salamon's thirdparty government theory, we show that and how outsourcing takes place. We also identify the rationales behind outsourcing from the perspective of the local governments. Second, we identify and examine the rationales behind networking behaviour by the NPOs, using network governance theory as proposed by Jones et al. as an analytical device. ${ }^{11}$

\subsection{Outsourcing Trends in Comparison}

The cooperation between local governments and NPOs in social service provision is defined by outsourcing activities from the former to the latter in most of the German and Chinese case studies. This section explores the characteristics and rationales of these outsourcing activities. Salamon's third-party government concept (1995) is used as a tool to deduct the characteristics of the outsourcing systems by analysing the case studies along the five criteria of third-party

10 The analytical part will concentrate on the first three heuristic devices. As for the high exchange frequency, we assume it is given in all the networks we analyse, otherwise we would not consider the network to exist (see 5.2.1).

11 The analysis largely refers to the 19 case study reports that have been analysed with the help of MAXQDA. References to the reports are derived from MAXQDA and are displayed in footnotes as follows: City\Policy Field_NPO Name: Paragraph. 
government as explained in Section 4. We will then explicate the rationales underlying the outsourcing activities, which were identified in the inductive content analysis.

\subsubsection{Outsourcing Characteristics}

Outsourcing activities from local governments to NPOs can be observed in 15 of the 19 cases analysed in this paper. Of these 15 outsourcing cases seven cases fulfill all five third-party government criteria in one way or another and eight cases fulfill three or four of the criteria. The four cases that display no outsourcing activities also hardly meet the third-party government criteria. They are the three cases of unsuccessful cooperation and one German grassroots organisation that does not maintain any direct cooperation with the local government (Berliner Stadtmission/ Refugio (Refugio)). The German case of Kein Abseits! e.V. (Kein Abseits) and the Chinese case of Guangzhou Dinghe Social Work Service Center (Dinghe), which show third-party government characteristics in an archetypal way, will be used below to illustrate the analysis criteria.

Kein Abseits is a Berlin-based association that offers mentoring services for child and youth refugees to enhance their opportunities. This NPO started in 2011 as a small private initiative and gradually grew as both the demand for services and its willingness to engage increased. In 2016 it began working with the government under the auspices of the Master Plan for Integration and Security (Masterplan Sicherheit und Integration - hereafter "Master Plan") developed to address the administrative challenges arising from the large numbers of refugees entering the country after 2015.

Dinghe is a non-profit service centre for homeless people in Guangzhou. It developed out of volunteer work and was able to register as a private nonenterprise unit (民办非企业单位, PNUs) ${ }^{12}$ in 2013 with the help of a private sponsor and the support of the local civil affairs bureau. In 2014 it won a contract in a competitive bidding process to receive government funding for a social assistance project for homeless people, and thereby began developing a closer collaborative relationship with the local authorities.

Both NPOs fulfill government functions and cooperate with local authorities in accordance with the third-party government criteria. However, Kein Abseits

12 Private non-enterprise units (PNUs) (民办非企业单位) are one of three officially regulated types of NPOs in Chinese law, the other two are foundations (基金会) and membership-based associations (社会团体). Since the introduction of the Charity Law in 2016, PNUs have been renamed social service organisations (社会服务机构). 
appears to pursue its own agenda within this framework, while Dinghe is developing into an agent of the state.

The next sections analyse and compare the outsourcing cases along the five third-party government criteria. Each section uses the two example cases to illustrate archetypal fulfillment of the criteria.

\subsubsection{Existence of Formalised Cooperation}

According to the third-party government concept, an NPO has to be officially recognised and cooperation must be formalised in some way to be successful. Contracting is a common form of formalised cooperation, but the third-party government concept goes beyond this to include other cooperative structures as well.

In all cases of successful cooperation in our sample, the NPOs are officially registered, a condition which grants them state recognition and the ability to act as legal persons on their own. The German NPOs in our sample are registered either as associations (e.V.) or private limited liability companies with public benefit status ( $\mathrm{gGmbH})$. The Chinese NPOs are registered as PNUs or membership-based associations (社会团体).

Kein Abseits! e.V. (Kein Abseits) is a registered non-profit association. In 2016 it answered a call for tenders from the Senate Department for Education, Youth and Family and entered a contractual relationship to receive funding for providing services in connection with the Master Plan. ${ }^{13}$ It has since also become officially recognised as a provider of child and youth welfare services (Träger der freien Kinder- und Jugendhilfe) ${ }^{14}$ It and similar NPOs receive funds from the German state on a contract basis for innovative and efficient solutions to challenges in service provision to refugees (see also e.g. RheinFlanke gGmbH [Rheinflanke], Auszugsmanagement, AWO Kreisverband Südost [AWO]).

In China, straightforward contracting usually takes place within a framework promoted in recent years by which the government purchases services (e.g. Superior Power Social Work Development Center [Superior Power], GZ Lawyers Association, Dinghe, Zhejiang Xiezhi vocational college [Xiezhi], Qidian Yixing). In Dinghe's case the local government in Guangzhou started a servicepurchasing initiative because it alone could no longer handle the increasing numbers of homeless people, mostly migrant workers. ${ }^{15}$ Because Dinghe's service provision met the requirements of the government, the Guangzhou civil affairs bureau and the NPO signed their first three-year contract in 2015. Since then, the

13 Berlin|Education_Kein Abseits_Berlin: 54-54.

14 Berlin|Education_Kein Abseits_Berlin: 15-15.

15 Guangzhou_en|Vulnerable Groups_Dinghe Social Workers: 3-3. 
Dinghe NPO provides the services in the contract and the government not only funds the daily expenses but has also purchased five additional projects. ${ }^{16}$

These examples show contracting as the most common form of formalised cooperation in our German-Chinese sample. All 15 outsourcing cases meet the criteria of formal cooperation in one way or another. In other forms of formalised cooperation the government employs or directly finances the project coordinator (e.g. Bridge network [Bridge], Chance+ Netzwerk Flüchtlinge and Arbeit [Chance+], Agisra), ${ }^{17}$ or the cooperation developed out of a joint idea and is based on an agreement that regulates the responsibilities of the involved parties (Guangdong Beida Economic and Trade College [Beida College]). ${ }^{18}$ In China, formalised cooperation can also display characteristics of a top-down government project, when the government establishes and completely controls the NPO's work based on a cooperation contract (HZ Lawyers Association, GZ Lawyers Association). ${ }^{19}$

\subsubsection{Transfer of Administrative Responsibilities}

The involvement of NPOs in public administration processes and the transfer of responsibilities from the government to NPOs is another criterion of third-party government, which specifies the form of cooperation between state and NPO.

Apart from the formalised cooperation described above, Kein Abseits is also involved in various public administration structures and not only receives government funding but also exercises public authority and assumes certain responsibilities. In its part of the city, the organisation is acknowledged as an important actor and influences public decision-making. ${ }^{20}$ As co-founder of the "Netzwerk Kinderpatenschaften" - a network of Berlin social organisations that offer mentoring services - Kein Abseits has an impact on Berlin's social agenda and organises the distribution of mentoring services for refugees throughout the whole city. ${ }^{21}$

Dinghe provides policy supervision and service guidance, and assumes government functions so as to increase awareness and satisfy basic needs of the people in Guangzhou. ${ }^{22}$ For example, it submitted a policy proposal in 2017 on NPO

16 Guangzhou_en|Vulnerable Groups_Dinghe Social Workers: 24-24.

17 Berlin\Employment_Bridge: 86-86; Cologne\Employment_Chance+: 8-8.

18 Guangzhou_en|Education_Beida College: 44-44.

19 Guangzhou_en\Social Assistance_GZ Lawyers Association: 49-49; Hangzhou_en|Social Assistance_HZ Lawyers Association: 30-30.

20 Berlin\Education_Kein Abseits_Berlin: 7-7.

21 Berlin|Education_Kein Abseits_Berlin: 45-45.

22 Guangzhou_en\Vulnerable Groups_Dinghe Social Workers: 58-58. 
social services for the homeless, ${ }^{23}$ and regularly publishes handbooks on NPO fields of work which not only provide guidance to social workers and NPOs but also seek to have an impact on public administration. ${ }^{24}$

This type of transfer of administrative responsibilities from governments to NPOs can be observed in seven of the cases in our sample. They fulfill all thirdparty government criteria of being intensely involved in governance processes and are exemplary cases of outsourcing.

\subsubsection{Complementary Cooperative Relationship}

Salamon $(1995,48)$ argues that both the state and NPOs have inherent limitations and that they therefore need cooperation partners. In the third-party government concept, the strengths of NPOs counterbalance the limitations of the state and vice versa. Cooperation is therefore characterised by a complementary distribution of functions and responsibilities.

Cooperation between Kein Abseits and the local government developed to address an urgent need on both sides. The NPO was facing financial and sustainability difficulties and struggling to gain public trust because many people hesitated to trust an organisation that was not well known and did not have the support of the government. ${ }^{25}$ At the same time, the local government was facing huge challenges in providing services to the incoming refugees and its administrative structures could not deal adequately with social inequalities. ${ }^{26}$ The biggest strength of Kein Abseits was its large number of volunteers and its innovative and flexible portfolio which the local authorities could not offer. ${ }^{27}$ For its part, the local government was able to provide funds, development perspectives and greater public recognition for the organisation.

Dinghe's cooperation with the government developed out of similar needs. The local government lacked the expertise and human resources to provide services for homeless people in Guangzhou and therefore sought a partner who could provide them. Dinghe was the first NPO to provide such services in Guangzhou and was ready to fill this gap. ${ }^{28}$ At the same time, it depends on regular funding and

23 The paper is called "Policy Proposal to Actively Guide the Intervention of Social Forces in Providing Social Assistance to Vagrants and Beggars”.

24 Guangzhou_en\Vulnerable Groups_Dinghe Social Workers: 50-50, Guangzhou_en\Vulnerable Groups_Dinghe Social Workers: 50-50.

25 Berlin\Education_Kein Abseits_Berlin: 40-40.

26 Berlin\Education_Kein Abseits_Berlin: 33-33.

27 Berlin\Education_Kein Abseits_Berlin: 68-68.

28 Guangzhou_en\Vulnerable Groups_Dinghe Social Workers: 9-9. 
administrative support and therefore depends on the complementary function of the government as purchaser of the services. ${ }^{29}$

A complementary cooperative relationship between the state and NPO appears to be a basic precondition for a functioning outsourcing relationship; certainly, all the outsourcing cases in our sample fulfill this criterion. A key function of the NPOs is the provision of services the government does not provide but considers important. This is a distinct tendency in the Chinese cases, where many services are not covered by social policy. For example, Xiezhi built a much-needed education and employment system in Hangzhou and won government support because the local administration failed to bear this responsibility and welcomed the opportunity to outsource the task. $^{30}$ In Germany, NPOs more commonly serve a bridging function between the government and the target group. They help the government gain better access to the target group (e.g. Bridge, AWO), support refugees in dealing with the complicated bureaucratic structures (e.g. Rheinflanke), and communicate directly with the target groups - all tasks which the local authorities apparently cannot accomplish (e.g. Chance+). Another important function of NPOs is to introduce expertise and innovative solutions, which often means that they train both public and private actors (e.g. Chance+, Xiezhi, Superior Power).

Besides allocating resources, the state also fulfills the function of providing a support environment for the NPO. This is particularly important in China, where NPOs depend on a favourable political environment in order to operate and gain some influence. The case of the Xiezhi NPO illustrates this function particularly well in its efforts to develop a cooperative relationship with the local government in order to receive policy support and build a good environment for its own development, even though it has sufficient private assets and does not depend on government resources. ${ }^{31}$

\subsubsection{Congruence of Goals}

A basic precondition for successful cooperation according to the third-party government concept is the pursuit of congruent public administration goals by the state and NPO.

Kein Abseits has an intrinsic motivation to improve the situation of young refugees. This NPO's vision is to build a society where everybody is engaged in volunteer work and where the social inclusion of refugees is a matter of course which does not need the support of public authorities anymore. ${ }^{32}$ With the

29 Guangzhou_en|Vulnerable Groups_Dinghe Social Workers: 27-27.

30 Hangzhou_en\Employment_Xiezhi: 30-30.

31 Hangzhou_en|Employment_Xiezhi: 29-29.

32 Berlin|Education_Kein Abseits_Berlin: 32-32. 
development of the Berlin government's Master Plan, which lists societal participation by refugees and civic engagement as key objectives, these goals officially became part of the public agenda. ${ }^{33}$

Dinghe assumes responsibility for social services that are desired by the government. In 2012, the Chinese central government issued the "Guiding Opinions of the Ministry of Civil Affairs on Promoting Social Forces to Participate in the Social Assistance to Vagrants and Beggars", which make this cooperation an important goal for the local government. ${ }^{34}$ As an organisation operating in lieu of the state, the NPO adapts to the goals of the local administration in this case. ${ }^{35}$

Cooperation in our sample is based mainly on common public administration goals. In both countries, state-NPO cooperation is only successful if the basic goals of the NPO correspond with the political agenda of the state. However, in Germany it is possible and common practice for NPOs to criticise existing public structures and advocate for different implementation of political goals (e.g. Bridge, Agisra), ${ }^{36}$ while the Chinese organisations see their role more as advisor to than advocate for the government (e.g. Superior Power, Dinghe). ${ }^{37}$

\subsubsection{Favourable Power Relation}

According to the third-party government concept, a favourable power relation is one in which the state has the advantage yet the NPOs cannot be completely overruled and must also have some influence.

Cooperation between Kein Abseits and the local administration is based on the guidelines stated in the policy agendas for providing social services to refugees, i.e. on the Master Plan and its follow-up, the Overall Concept for the Integration and Participation of Refugees (Gesamtkonzept zur Integration und Teilhabe Geflüchteter). Kein Abseits first had to apply for funds and adapt to the requirements of these government concepts. While this led to a structural imbalance of power in favour of the state, the NPO could still influence the policy-making process. It managed to become a relevant and established player in local public administration and was therefore able to build a cooperative relationship with local authorities based on mutual trust and understanding. On this basis, the NPO gradually enjoyed greater autonomy and authority. ${ }^{38}$

33 Berlin\Education_Kein Abseits_Berlin: 53-53.

34 Guangzhou_en|Vulnerable Groups_Dinghe Social Workers: 60-60.

35 Guangzhou_en|Vulnerable Groups_Dinghe Social Workers: 50-50.

36 Berlin|Employment_Bridge: 97-97.

37 Guangzhou_en|Employment_Superior Power: 9-9; Guangzhou_en|Employment_Superior Power: 9-9.

38 Berlin|Education_Kein Abseits_Berlin: 69-69. 
Dinghe signed a contract with the local government that determines the rights and obligations of both parties. It specifies instructions for the execution of service provision by the NPO and grants the government the right to supervise and assess project implementation. If the government is not satisfied with the NPO's performance, it can terminate the contract and refuse to pay any further funds. ${ }^{39}$ The government therefore has a strong power advantage in this cooperative relationship, and the NPO must conform to the government's requirements if it wants to sustain the relationship. However, Dinghe is successful in offering services that the government cannot provide, and the local authorities therefore depend on its capabilities. The NPO successfully influences policy making and has an independent board of directors, which manages its daily business. ${ }^{40}$

The legal basis can therefore grant more power to the government in such a cooperation, but successful and self-confident NPOs can build their own influence and keep a certain level of autonomy. Besides guidelines, regulations and contracts designed by the state, the government's power usually derives from resources that it can terminate any time or from approval that it must renew at regular intervals (e.g. Bridge, AWO, Beida College, Qidian Yixing). Staff overlaps, when for example the NPO project co-ordinator is employed by a public agency, also function as an instrument of control (Bridge, Chance+). ${ }^{41}$ In the Chinese case of cooperative relations the government generally clearly holds a dominant position. Only by winning the trust of the government and pursuing goals that it favours can the NPOs work relatively undisturbed, assume public responsibilities and even influence decision-making processes (e.g. Superior Power). ${ }^{42}$ Twelve of 15 outsourcing cases in our sample fulfill this criterion. The exception in Germany does not stand in a hierarchical relationship with the government (Agisra), while the Chinese exceptions are completely controlled by the government and have no autonomy at all (Hangzhou and GZ Lawyers Association).

\subsubsection{Rationales for Outsourcing Services by Local Governments}

The analysis of outsourcing characteristics shows that services are outsourced from local governments to NPOs in 15 of the 19 case studies. Four main government motivations for doing so are identified: 1 ) to support the provision of public services; 2) to fulfill guidelines set by higher administrative levels; 3) to derive support

39 Guangzhou_en|Vulnerable Groups_Dinghe Social Workers: 27-27.

40 Guangzhou_en|Vulnerable Groups_ Dinghe Social Workers: 61-61; Guangzhou_en|Vulnerable Groups_Dinghe Social Workers: 8-8.

41 Berlin\Employment_Bridge: 65-65.

42 Guangzhou_en|Employment_Superior Power: 54-54. 
Table 1: Characteristics of NPO support for public services provisions.

\begin{tabular}{lll}
\hline & $\begin{array}{l}\text { The state offers social services } \\
\text { in this field } \\
\text { Competing services (no } \\
\text { outsourcing) }\end{array}$ & $\begin{array}{l}\text { The state does not offer } \\
\text { social services in this field } \\
\text { The NPO offers the same ser- } \\
\text { vices in parallel to the state } \\
\begin{array}{l}\text { The NPO services complement } \\
\text { the state services }\end{array}\end{array}$ \\
$\begin{array}{ll}\text { Tiveness of service provision } \\
\text { (German outsourcing model) }\end{array}$ & $X$ \\
state does not & $X$ & $\begin{array}{l}\text { Facilitate efficacy of services } \\
\text { (Chinese outsourcing model) }\end{array}$ \\
\hline
\end{tabular}

from NPO expertise; and 4) in the Chinese cases: to maintain control and social stability. These four categories are examined below to determine the rationales behind local government outsourcing of services to NPOs.

\subsubsection{Support Public Service Provision}

In all outsourcing cases, cooperation with the NPO was established to support the government in providing public services. Its character depends on whether the state offers any services in the respective field itself and whether the NPO offers the same services or complements those of the government. Competing parallel services by the state and NPO in the same field occur only in cases that do not show the characteristics of outsourcing from the local government to the NPO. Outsourcing therefore happens when NPOs complement government services to improve efficiency and effectiveness of service provision or when they provide services the state would otherwise not offer, also to improve efficacy (see Table 1).

In all German outsourcing cases, the NPOs complement the services provided by the local government. This implies that the local administrations in Germany offer services in all policy fields that we studied, but these are not sufficient or require support and NPOs to fill gaps. Except for the two networks, Bridge and Chance+, which were founded as part of the federal program ESF Integration Guideline (ESF-Integrationsrichtlinie Bund) to build local networks, in all German cases the NPOs initiated their projects and took action to foster cooperation with the local government. They develop projects where there are problems and gaps in service provision by the state, and local administrations develop cooperation with these NPOs to support and direct their work and to make use of their expertise and innovative capacities. In these cases, cooperative relations serve to improve the efficiency and effectiveness of services. On the one hand, NPOs offer efficient solutions in contrast to what can be bureaucratic and inflexible characteristics of local administrations in Germany. For example, the Kein Abseits NPO offers low threshold mentoring and education services for refugees who cannot benefit from 
services by the city administration because the bureaucratic preconditions and hurdles are too high. ${ }^{43}$ In the case of Auszugsmanagement in Cologne, the NPOs in the network have developed a system to provide cheap and flexible housing options for refugees and approached the city administration to work together for better housing conditions. Because ongoing demand had pushed municipal services to their limits, the city took Auszugsmanagement's more efficient solution into its service portfolio. ${ }^{44}$ On the other hand, NPOs support the effectiveness of government services when e.g. the local administration struggles to access the target group. The NPOs build bridges between the target group and the administration and thereby support the latter's services. Especially when dealing with vulnerable groups, good connections and a basis of trust are needed. For example, AWO in Berlin and Agisra in Cologne both have a long tradition of offering social services for women in need and facilitating access by female refugees to public services. $^{45}$

The Chinese cases of successful cooperation show a different picture of the nature of NPO support for public services. While the German outsourcing models in our cases complement the government services, the NPOs in the Chinese cases offer services the state would otherwise not provide (see Table 1). This implies that the Chinese state cannot or does not want to provide its own services in the policy fields studied but instead relies on third-party providers to do so. The cases in our sample fall into three different categories: 1) the government takes the lead and initiates the project and cooperation (Superior Power, GZ and HZ Lawyers Associations, Dinghe, Qidianyixing Social Work Development Center [Qidianyixing]); 2) the NPOs are the initiators and the government then transfers the responsibility for these services to the NPO (Hangzhou Net, Xiezhi); and 3) one case in which the government and NPO take joint action to tackle a social problem (Beida College). In all these cases, the NPOs make public service provision more effective. In the Chinese cases, the state wants to take pressure off local administrations and develop solutions for social challenges at the same time. With the lawyers' associations in Guangzhou and Hangzhou, for example, this happens in a top-down manner by which the government establishes the NPOs and directs their actions to create public services. By contrast, Xiezhi in Hangzhou is a bottom-up development by which services are provided that were originally the responsibility of the government but the local administration did not succeed and subsequently

43 Berlin|Education_Kein Abseits_Berlin: 33-33.

44 Cologne $\backslash$ Social Assistance_Auszugsmanagement: 58-58.

45 Berlin\Vulnerable Groups_AWO Frauenberatung: 46-46; Cologne|Vulnerable groups_Agisra: 44-44. 
embraced the solution offered by the NPO. ${ }^{46}$ In other cases, social services provided by NPOs are arranged by the government to deal with new challenges resulting from large numbers of migrant workers entering the cities. One example would be Superior Power in Guangzhou, where the local government has responded to social unrest and asked the NPO to develop new services. ${ }^{47}$

\subsubsection{Fulfill Guidelines Set by Higher Administrative Levels}

In both Germany and China, local governments have additional reasons for establishing cooperative relationships with NPOs, such as the need to follow guidelines from higher administrative levels. In nine of the 15 outsourcing cases in our sample, concrete guidelines or programs are mentioned as a reason for the local government to seek cooperation with NPOs. The respective guidelines are city-specific. In Berlin, the Master Plan has strongly promoted state-society cooperation to integrate refugees. In Cologne, no such overall program for refugees has been instituted but smaller guidelines such as the city council's decision to promote the integration of refugee children and youth has influenced cooperation in our case studies. In China, Guangzhou has the special status of "Model City for Service and Management of Floating Population and Ethnic Minorities”, which means that the central government regards it as a pioneer city with pilot state-society cooperative projects to integrate the floating population (Ketels 2019, 7). All successful cases in Guangzhou have developed as a result of this status and the corresponding expectations. Several additional guidelines such as the Guangzhou Social Work Service Matrix of "General Service + Specialized Service" or the "Guiding Opinions of the Ministry of Civil Affairs on Promoting Social Forces to Participate in the Social Assistance to Vagrants and Beggars" have further promoted cooperation in our sample. In Hangzhou, the influence of such guidelines is much weaker. Except for the lawyers' association, which was founded in accordance with national guidelines, no superior guidelines are mentioned. The majority of cases in Hangzhou are projects that developed out of grassroots movements or individual engagement and were later engaged by the government (Hangzhou Net Volunteer Branch [HZ Net], Xiezhi, Home of Grassroots [Grassroots]).

\subsubsection{Derive Support from NPO Expertise}

Another objective of local governments in cooperating with NPOs is to benefit from NPO expertise in their policy-making processes and/or make use of NPO abilities to train public officials and social workers. Eight case studies explicitly give this rationale, with no difference in meaning between China and Germany. For Bridge

46 Hangzhou_en|Employment_Xiezhi: 30-30.

47 Guangzhou_en|Employment_Superior Power: 52-52. 
and Chance+ in Germany, for example, the ESF Integration Guideline that promotes and funds the cooperation explicitly states the goal of gaining experience and providing information to policy makers and other public actors. In China, projects and cooperation with e.g. the lawyers' associations in Hangzhou and Guangzhou are explicitly developed by the government to utilise the expertise of the lawyers for government objectives.

\subsubsection{Maintain Control and Social Stability}

The fourth rationale has only been identified in the Chinese cases. Maintaining control and social stability is a factor mentioned in every Chinese case as a major reason for local governments to co-operate with NPOs in providing social services. This factor has two aspects: on the one hand, the government wants to reduce risks to social stability by addressing factors in social unrest and entrusts the NPOs with doing so. In the case of Dinghe, for example, the government seeks a way to deal with the potential for social unrest arising from homeless people on the streets of Guangzhou and consequently initiates cooperation with an NPO that offers solutions. On the other hand, the government seeks to control and channel the productivity of certain groups in accordance with government objectives. Regarding the lawyers' associations, for example, the NPOs serve to control and utilise legal specialists by issuing lists of lawyers' social responsibilities and recruiting them for voluntary services directed by government agencies. ${ }^{48}$ In the case of Beida College the NPO helps to channel and control the migrant workforce as desired by local government to avoid social unrest and instead to promote Guangzhou's development. ${ }^{49}$

\subsection{Networking Trends in Comparison}

All the cases in our sample applied networking to various degrees in their work strategies. In this section we first - inductively - describe the various networking activities $^{50}$ that occurred in our case studies (5.2.1); in a second step we then apply - deductively - the operationalised theory of Jones et al. (1997) on network

48 Guangzhou_en|Social Assistance_GZ Lawyers Association: 37-37.

49 Guangzhou_en|Education_Beida College: 68-68.

50 In practice, the boundaries between cooperation and networking can be blurred. For the analysis in this report, we distinguish cooperation and networking as follows: Cooperation is directly related to the creation of the product/service that is offered by the NPO, whereas networking activities indirectly support this creative process. For example, cooperation is the case when the local government signs a contract with or informally has the NPO provide a certain service, whereas networking applies when the NPO and representatives of local state authorities 
governance to understand the rationales behind these networking activities (5.2.2). Since networking is an essential part of the work of all the organisations in our sample, this section will not feature a "model case" but rather analyse and compare the cases along the categories developed from the literature on network governance.

\subsubsection{Existence of Networks}

As mentioned above, all the NPOs in our cases were embedded in some kind of network, albeit to different degrees and of different network size. We identified the following types: 1) those centring around German and Chinese organisations that are themselves organised as networks; 2) German and Chinese organisations that have built complex stakeholder networks; 3) German networks that explicitly do not include government agents; and 4) Chinese networks that are under the supervision and leadership of a local government agent.

First, some of the NPOs are themselves networks: in Germany Chance+ and Bridge are networks comprising other NPOs, government agents, other networks, and cooperation partners for service provision. In both cases the government had explicitly looked for networked organisations in the bidding process. ${ }^{51}$ In the case of Auszugsmanagement, the local government itself has started organising coordination meetings to build up the network for finding accommodation for refugees. ${ }^{52}$ In the case of the AWO Kreisverband, it is embedded in the large network of the umbrella organisation AWO. Beida College can also be placed in this category, as a network of the Guangdong Beida College of Economics and Trade, the Beida Alumni Association, other universities and the Guangdong Provincial Government. ${ }^{53}$ Kein Abseits is similarly a network and has initiated several new networks as well. That includes contacts with sponsors and with many other organisations and institutions to recruit mentors for their programmes. This network is composed primarily of stakeholders and involves only few government agents.

Second, other organisations are not set up as networks themselves but have built up networks that include all relevant stakeholders of the respective project(s) they conduct and services they offer. Xiezhi in Hangzhou, for instance, has built a network that connects the organisation with various levels of government agencies and Communist Party officials in Hangzhou City, Zhejiang Province and the capital

meet regularly at roundtable meetings to ensure similar understanding of the services the state purchases from the NPO.

51 Cologne $\mid$ Employment_Chance+: 60-60, Berlin|Employment_Bridge: 50-50.

52 Cologne $\backslash$ Social Assistance_Auszugsmanagement: 14-14.

53 Guangzhou_en|Education_Beida College: 3-3. 
Beijing. A considerable portion of the network consists of funders: Xiezhi is funded by various foundations (YouChange Entrepreneur Foundation for Poverty Alleviation, Zengai Charity Foundation and Zhejiang Women and Children Foundation) and by large enterprises such as Alibaba. The network also includes companies that are potential employers for the migrant workers lodged at and trained by Xiezhi's different facilities and the universities that use its big data employment intermediation services. In addition, the leader of Xiezhi is a member of the board of a regional development centre (which might also be interested in the services Xiezhi offers). Xiezhi also maintains close relations with all important media agencies and outlets. Similarly, the German organisation Refugio is centred around a shared housing space and coffee shop, and has built a network that consists of all the important stakeholders. It is managed by the Berliner Stadtmission, which is under the umbrella of the Protestant Church which is a huge network organisation itself. Like Xiezhi, Refugio also combines its social services with for-profit enterprises, albeit on a smaller scale. The Refugio café is an enterprise that helps finance the organisation's work, but it is also the venue for language courses for Refugio's target group and simultaneously a channel through which the organisation involves its neighbourhood in its endeavours. Furthermore, it maintains a relationship with the Technical University in Berlin by helping to design a rooftop garden for the university. Rheinflanke is organised around its services for young people in homes for asylum seekers, and offers leisure activities and education programmes. It is organised in the form of a stakeholder network that includes sponsors, resources for its services and government agents, i.e. complementary providers of services, skilled personnel and expertise. These stakeholder networks generally include government agents.

Third, another group (in Germany only) is embedded in networks that do not include government officials. Agisra is such a case. It is a member of the umbrella organisation Deutscher Paritätischer Wohlfahrtsverband, as well as of other working groups and networks (German and international). It has initiated an umbrella association itself and cooperates with the media. Agisra does not receive funds from the government. Be an Angel, one of the cases that turned out to be unsuccessful in terms of its cooperation with the local government, is another example of an NPO with a network that tends to exclude government-related members.

Fourth, in several Chinese cases the government agents have supervisory functions in the networks of which they are members. For instance, Dinghe's project for homeless people in Guangzhou is part of the local government's network of "rescue stations" on municipal and district levels and a volunteer service that is also supervised by the local government's office of social affairs. 
Although the two lawyers' associations in Hangzhou and Guangzhou are huge networks, ${ }^{54}$ due to their politically sensitive membership (lawyers and law firms) and the work they do (counselling in labour disputes) they are closely supervised by the local governments of their localities. Superior Power also belongs to this category of networks, having been invited by the government to take over research and supervision work for the government. Like other Chinese organisations, it has instituted a certain network in its governance structure, with three external directors on its board, one each from the media, a university and a law firm. HZ Net is a branch organisation of Hangzhou Charity Federation, which is a membership-based non-governmental organisation in the city. It has an extensive network due to the widespread connections of the Hangzhou Charity Federation, consisting of media and government representatives and volunteer recruitment resources. According to the field report, the local government has a guiding role that extends beyond the service contract signed between it and $\mathrm{HZ}$ Net.

The three cases in our sample which we regard as having failed in their cooperation with the government are embedded in networks as follows. The Volunteer Service for Sanitation Workers (Sanitation Workers) has a very small network that consists primarily of its volunteers on the one hand, and of the sanitation station and community neighbourhood committee on the other which have to be considered representatives of the local state in the organisation's area of activity. One reason for the inability to extend the network seems to be the fact that Sanitation Workers was not able to register officially and therefore cannot act as a legal person on its own. The second Chinese "failed" case is Grassroots. This organisation initially had a network of sponsors but subsequently lost all its connections to them when it became part of the local government administration. The fact that its legal status was unclear, because it was not registered as a social organisation but as a business enterprise, may have contributed to its problems. The German "failed" case, Be an Angel, is embedded in a network of type 3 (a stakeholder network without particularly close government relations). The field report explains its failure in part by the weak relationships among the network's members.

Table 2 provides an overview of the types of networks we identified in our sample cases.

Table 2 shows first of all that all the organisations in our sample work in networks, and second that different variants seem to be more common in one

54 According to the field reports, the Guangzhou Lawyers Network has 15,000 individual and 700 group members, while the Hangzhou Lawyers Network has 7213 individual members and 487 group members. 
Table 2: Overview of network types of sample cases.

\begin{tabular}{|c|c|}
\hline NPO name & Network type \\
\hline Kein Abseits! e.V. & (1) Network organisation \\
\hline Bridge Network & (1) Network organisation \\
\hline AWO Kreisverband Südost Women's Counselling Center & (1) Network organisation \\
\hline Chance+ Netzwerk Flüchtlinge und Arbeit & (1) Network organisation \\
\hline Auszugsmanagement & (1) Network organisation \\
\hline $\begin{array}{l}\text { 广东北达经贸专修学院 Guangdong Beida Economic and } \\
\text { Trade College }\end{array}$ & (1) Network organisation \\
\hline Berliner Stadtmission (Refugio) & (2) Stakeholder network \\
\hline RheinFlanke gGmbH & (2) Stakeholder network \\
\hline $\begin{array}{l}\text { 杭州市慈善总会杭州网义工分会 Hangzhou Net Volunteer } \\
\text { Branch of Hangzhou Charity Federation }\end{array}$ & (2) Stakeholder network \\
\hline 浙江携职专修学院 Zhejiang Xiezhi Vocational College & (2) Stakeholder network \\
\hline Be an Angel e.V. & $\begin{array}{l}\text { (3) Network exclusive of govern- } \\
\text { ment agents }\end{array}$ \\
\hline AGISRA e.V. & $\begin{array}{l}\text { (3) Network exclusive of govern- } \\
\text { ment agents }\end{array}$ \\
\hline 广州市黄埔区优势力社会工作发展中心 Superior Power & (4) Stakeholder network, super- \\
\hline Social Work Development Center & vised by local government \\
\hline 广州市律师协会 Guangzhou Lawyers Association & $\begin{array}{l}\text { (4) Stakeholder network, super- } \\
\text { vised by local government }\end{array}$ \\
\hline $\begin{array}{l}\text { 广州市鼎和社会工作服务中心Guangzhou Dinghe Social } \\
\text { Work Service Center }\end{array}$ & $\begin{array}{l}\text { (4) Stakeholder network, super- } \\
\text { vised by local government }\end{array}$ \\
\hline 杭州律师协会 Hangzhou Lawyers Association & $\begin{array}{l}\text { (4) Stakeholder network, super- } \\
\text { vised by local government }\end{array}$ \\
\hline 杭州市下城区起点益行社会工作发展中心 Qidianyixing & (4) Stakeholder network, super- \\
\hline Social Work Development Center & vised by local government \\
\hline $\begin{array}{l}\text { 关爱环卫工人志愿服务队Volunteer Service for Sanitation } \\
\text { Workers }\end{array}$ & $\begin{array}{l}\text { Apparently, very small or no func- } \\
\text { tioning network. }{ }^{\text {a }}\end{array}$ \\
\hline 草根之家 Home of the grassroots & $\begin{array}{l}\text { Apparently, no functioning } \\
\text { network. }^{\text {b }}\end{array}$ \\
\hline
\end{tabular}

${ }^{a}$ The Volunteer Service for Sanitation workers uses its network, which is mainly composed of the neighbourhood committee members, mainly for recruiting volunteer workers. ${ }^{b}$ The network of this organisation, which was mainly composed of sponsors, dissolved completely after the organization took up relations with the government.

country than in the other. Most of the German cases are network organisations themselves embedded in larger stakeholder networks. Organisations embedded in stakeholder networks with and without government agents exist in both Germany and China. While in Germany we see stakeholder networks with and without government agents, the dominant Chinese variant in our sample is an organisation embedded in a stakeholder network under the supervision of the local government. 


\subsubsection{Rationales for NPO Networking}

We will now look at the rationales behind the networking activities of the NPOs in our sample. According to Jones, Hesterly, and Borgatti (1997), organisations tend to make use of network governance under three exchange conditions: 1) asset specificity, i.e. when the NPOs need special skills and knowledge to offer their services; 2) funding uncertainty, i.e. when the NPOs work under conditions such as short-term funding or fierce competition in government bidding processes that make long-term planning difficult; 3) task complexity, i.e. when the organisations conduct tasks that involve multiple stakeholders and/or multiple problems and/or require multiple kinds of expertise.

\subsubsection{Exchange Condition: Asset Specificity}

Jones et al. found evidence that business organisations tend to build networks when they need special knowledge and skills to deliver their products. We find that this also pertains to the NPOs in our case studies. The field reports analysed contain ample evidence of the NPOs maintaining networks in order to utilise the skills and knowledge of their different members. In particular, the NPOs use these assets to: 1) improve their visibility in the public and the media; 2) ensure access to vital information for their work; 3) make use of for-profit entities for their non-profit work; 4) ensure access to expert knowledge for the provision of their services; and 5) function as an information platform in their field of expertise as one of the services in their portfolios.

(1) Improving NPO visibility

Despite the different roles of the media and the different degrees of media freedom in Germany and China, we found that the NPOs in our sample maintain close relations to news media representatives in both countries. Beida College worked together with the Southern Newspaper Group, Guangdong Telecom Company and Xinhua Net in raising funds and doing promotional activities during the start-up phase of its organisation. ${ }^{55}$ Superior Power invited a reporter from Yangcheng Evening News onto its board of directors. ${ }^{56}$ The founders of Xiezhi and of Dinghe are trained media professionals themselves (news anchorman and journalist). The interviewees from HZ Net also underscored the organisation's media connections. ${ }^{57}$ The restaurant managed by Be an Angel is praised in the media, ${ }^{58}$ and Be

55 Guangzhou_en|Education_Beida College: 48-48.

56 Guangzhou_en|Employment_Superior Power: 12-12.

57 Hangzhou_en\Education_HZ Net Voluntary Branch: 31-31.

58 Berlin|Unsuccessfull_Be an Angel: 62-64. 
an Angel also uses the media for advocacy purposes. ${ }^{59}$ Rheinflanke's board of trustees is "manned with celebrities from film and television [...]".60

(2) Ensuring NPO access to information vital for their work.

Successful NPOs need access to government information, including administrative requirements and bidding processes. Many of them therefore include government personnel in their networks (as shown in Section 5.2.1 on network existence). While government connections are usually the best choice for Chinese NPOs in terms of informational access, in Germany connections to one of the big umbrella organisations or churches can also be helpful in this respect. Accordingly, many of our sample NPOs are in fact members of umbrella organisations: Agisra and Rheinflanke are members of the Deutscher Paritätischer Wohlfahrtsverband, ${ }^{61}$ Chance+ Network and Auszugsmanagement belong to the Catholic Caritas Verband, ${ }^{62}$ and the AWO Kreisverband is part of the Arbeiterwohlfahrt (AWO).

(3) Making use of for-profit entities for their non-profit work.

A number of NPOs in our sample combined their welfare services with business enterprises, often coffee shops or restaurants but also other for-profit activities. Along with generating additional income, working with (or sometimes establishing) for-profit entities can provide potential workplaces to the clients of employment NPOs (e.g. the cooperation between Xiezhi and Alibaba and other regional firms), venues for education and training (e.g. the cooperation between Bridge and Vivantes), or places to live (such as Refugio's co-habitation house). ${ }^{63}$ A third function of such set-ups is to foster networking and exchange among clients (such as the Rheinflanke and Refugio cafés). Sometimes this type of cooperation fulfills more than one function, such as Be an Angel's "Kreuzberger Himmel" restaurant which is a venue both for generating income and training the NPO's clients). Xiezhi specialised in big data technology and set up its own business. The firm uses big data to facilitate more efficient and effective matching between the country's job

59 Berlin\Unsuccessfull_Be an Angel: 33-33.

60 Cologne\Education_Rheinflanke: 31-31.

61 Cologne \Vulnerable groups_Agisra: 28-28; Cologne\Education_Rheinflanke: 32-32.

62 Cologne\Employment_Chance+: 31-31; Cologne\Social Assistance_Auszugsmanagement: 6-6. 63 Refugio is not profit-oriented, but generates some rental income: While the staff of the Refugio house is paid by the Stadtmission, which also owns the building, the inhabitants either pay their rents from earned incomes or have their housing costs covered by public entities (e.g. the job centres) if they are unemployed or if their incomes are insufficient to cover living expenses (Berlin\Social Assistance_Refugio: 19-21). 
advertisements and the graduates of its universities, ${ }^{64}$ thereby generating income, promoting its connection with universities throughout China, and solving the problem of matching talent and job opportunities.

(4) Ensuring access to expert knowledge for the provision of services.

Probably the most widespread function of NPO networks is to have experts at hand for the provision of services. These experts might be lawyers, instructors or other experts who are willing to share their knowledge and skills with the NPO's clients. Dinghe, for example, maintains contact with 15 public welfare organisations in the 'Guangzhou Street Friends Care Service Alliance' to provide training in handicraft production and legal consultation for vagrants and beggars. ${ }^{65}$ The teachers at Beida College come from their "teaching resources network," which consists of 54 colleges and universities "including Peking University, Renmin University of China, Zhejiang University, Sun Yat-sen University and South China University of Technology." ${ }^{66}$ For its HaPiEnd project, the Agisra NPO connects its clients (refugee women) with "motivated craftswomen or volunteers and provides the necessary materials and tools" to help them renovate their flats before moving in. ${ }^{67}$ Kein Abseits recruits students from Berlin universities to mentor young refugees and help them with their school homework and in communications with the authorities. ${ }^{68}$ Auszugsmanagement, which originally focussed on finding and renting accommodation for refugees, discovered that its clients often need further assistance and counselling. It therefore set up a network of related "public institutions, social organisations and welcome initiatives" that can provide professional assistance. ${ }^{69}$ Although this is a tendency throughout the two countries investigated, we found that Chinese NPOs are often closely connected to universities and also involved in research projects, while that applies to only some of the German NPOs in our sample. ${ }^{70}$

64 Hangzhou_en\Employment_Xiezhi: 54-54.

65 Guangzhou_en|Vulnerable Groups_Dinghe Social Workers: 19-19.

66 Guangzhou_en|Education_Beida College: 20-20; Guangzhou_en|Education_Beida College: 56-56.

67 Cologne|Vulnerable groups_Agisra: 37-37.

68 Berlin|Education_Kein Abseits_Berlin: 41-41.

69 Cologne\Social Assistance_Auszugsmanagement: 73-73.

70 Kein Abseits! is no exception to this observation because its existing connections to Berlin's universities serve no scientific purposes but rather the recruitment of mentors for the education services of this NPO. 
(5) Functioning as an information platform in their field of expertise (Internet, social media etc.)

Because NPOs accumulate considerable knowledge, skills and contacts in their day-today work, these organisations naturally tend to set up their own information platforms or even establish their own think tanks. This is especially true for China, where the NPOs in our sample very often had close connections to academic institutions and were often initiated by intellectuals. Superior Power, for instance, set up "the Private Think Tank for Social Construction in Guangdong” on issues of government, philanthropy, women and corporations. ${ }^{71} \mathrm{GZ}$ Lawyers Association uses online platforms to provide innovative legal aid, "including legal counselling, legal publicizing and legal training." With this technology, and especially mobile apps like WeChat, more clients can be reached and more information disseminated in more effective and efficient manners than offline. ${ }^{72}$

In short, German and Chinese NPOs make ample use of networks and the associated knowledge and skills in order to raise their visibility (and thereby increase both public trust and donation income), ensure access to vital information for their work, collaborate with for-profit enterprises, and secure access to expertise needed for their manifold services, as well as to build platforms to share the information they accumulate in their projects.

\subsubsection{Exchange Condition: Funding Uncertainty}

Jones et al. also found evidence that organisations build networks to mitigate the transaction costs for "demand uncertainty". In the cases they investigated, such uncertainty would occur for example when the many companies involved in producing movies for the film industry went through periods of uncertainty concerning subsequent commissions. We find that the NPOs in our sample actually do not face demand uncertainty simply because the demand for their services is overwhelming. However, there is a funding uncertainty that similarly affects the NPOs in our sample.

The problem for most of the NPOs is not so much whether they can get contracts but rather for how long, because access to public funds requires a constant process of application and reapplication. ${ }^{73}$ Another funding-related problem in some cases is that it can be limited to certain areas. Chance+, for example, found during one project phase that their clients needed a certain type of counselling. So they changed part of the project to meet this demand but were not allowed to transfer the corresponding part of the budget. ${ }^{74}$ We found that in such situations the NPOs in our sample

71 Guangzhou_en|Employment_Superior Power: 22-22.

72 Guangzhou_en|Social Assistance_GZ Lawyers Association: 52-52.

73 Berlin|Employment_Bridge: 111-111; Berlin\Unsuccessfull_Be an Angel: 18-18.

74 Cologne|Employment_Chance+: 88-88. 
resorted to networks, similar to the supplier companies in the film industry. Many of the reports in our sample tell of networking with potential funders, both in China and in Germany. ${ }^{75}$ Usually the NPOs have to contact a number of different funders in order to conduct one project. Rheinflanke runs part of its projects with funds from the European Union and other parts from different departments on different levels of government. ${ }^{76}$ Kein Abseits receives public funding for $30 \%$ of its work and needs to solicit the rest of its funds from other sources. ${ }^{77}$ In some cases it takes years to secure a commitment by local governments to fund certain projects or programmes. Administrative requirements for NPOs applying for public funding can include reporting requirements that may have an impact on their work. ${ }^{78}$ In some cases the requirements for certain licenses to prove their capabilities can also mean additional expenditures that the NPOs cannot afford. ${ }^{79}$ Some NPOs in China, however, seem to be confident of long-term funding once they have gone through and succeeded in the competitive bidding process. This seems to be particularly true for those NPOs that take over government functions, such as Dinghe and Superior Power.

In short, although the NPOs see a high demand for their services most of them face difficult funding situations. Cooperation within networks helps them to secure funding by establishing reciprocal relationships and connections on a long-term basis.

\subsubsection{Exchange Condition: Task Complexity}

Another similarity between the NPOs in our sample and the groups researched by Jones et al. is the fact that their tasks are highly complex. Helping to integrate migrants and refugees poses challenges to local governments. Complexity occurs because of: 1) the high numbers of people and parties involved, such as the high numbers of refugees in Germany and migrants in China requiring assistance; 2) the complex problems that require complex solutions, e.g. housing problems sometimes entail psychological problems, as shown by the case of Auszugsmanagement; 3) the generally scattered nature of the resources needed to solve these problems, including volunteers, experts, potential landlords and employers, as well as funds and media support.

Although the target groups and the political-legal and social backgrounds differ between China and Germany, some of the challenges are similar. And the NPOs, again, turn to networks to deal with them.

75 For example: Hangzhou_en|Employment_Xiezhi: 54-54; Berlin\Employment_Bridge: 110-110; Guangzhou_en|Education_Beida College: 61-61; Cologne|Vulnerable groups_Agisra: 56-56; Cologne Education_Rheinflanke: 69-69.

76 Cologne|Education_Rheinflanke: 42-44; Cologne|Education_Rheinflanke: 55-55.

77 Cologne|Employment_Chance+: 59-59.

78 Berlin|Employment_Bridge: 112-112.

79 Berlin\Unsuccessfull_Be an Angel: 37-37. 
(1) High numbers of people and parties involved.

One challenge is the generally large number of parties involved - target groups, experts, funders have all to be approached in a coordinated way. The numbers of people involved in China are much higher than those in Germany. The organisations use their networks in responding to this challenge. NPOs incorporated into networks themselves can organise large numbers of helpers to address these challenges. The two above-mentioned lawyers' associations in China and the Bridge and Chance+ networks in Germany are examples of this strategy.

(2) The problems to be solved are complex and demand complex solutions.

The examples of the employment NPOs and their solutions show how many different tasks, fields of expertise and people are needed to facilitate employment for newly arrived refugees in Germany or migrants in China. In addition to potential employers, these include specialists in temporary housing as well as language, professional and other instructors. Again, as seen above, the NPOs utilise their extensive networks to provide multi-facetted solutions.

(3) The resources for solving the problems are scattered.

Similarly, networks are needed because there is usually no single source that satisfies all the different requirements for a given problem. The section on asset specificity above showed how NPOs build networks to access expertise, knowledge and personnel that cannot be acquired from one specific source or provider.

To conclude, networking is a trend observed in all of our cases in Germany and China. Organisations use networks to connect and cooperate in relationships that are usually not governed by contracts to deal with the high demands on their skills and knowledge (asset specificity), the uncertainty of their funding and the complexity of their tasks, thereby ensuring access to the greatest possible number of sources to help them solve pressing problems in their societies.

\section{Conclusion}

In this study we examined characteristics and rationales of state-NPO cooperation. Based on a qualitative analysis of field research reports on 19 German and Chinese cases of NPOs working in the field of migration we began with an analysis of the outsourcing activities by local governments in China and Germany that revealed many parallels but also some fundamental differences. In analysing our case studies, we found outsourcing of public services in the sense of Salamon's third-party government 
approach to be a practice in most of the German and Chinese cases in our sample. The cases show outsourcing characteristics across different relationship types, countries and policy fields. Seven (three Chinese and four German) of the cases analysed even display a transfer of administrative responsibilities from local governments to NPOs and show intense involvement by the NPOs in governance processes. In the German cases, less successful outsourcing structures in the third-party government sense correspond with less formalised forms of cooperation. In the Chinese cases, outsourcing structures appear to be negatively affected by an asymmetric power relationship that favours the government. Regarding the rationales for local governments to outsource services, the data from our sample showed that those in Germany turned to NPOs to complement existing services, while those in China outsource services that would otherwise not be offered at all. Outsourcing therefore improves the efficiency and effectiveness of public service provision in the German cases and facilitates the efficacy of public service provision in China. This finding underscores the observation that China's development model has long departed from the socialist idea of the state being responsible for all areas of society. In a way, the state in China is willing to outsource some of its responsibilities to a high degree while maintaining ultimate control, while in Germany's social market economy many responsibilities remain in the state's hands and local governments seem to prefer to solve social problems in a cooperative manner with NPOs. In light of this first finding, these insights show that an authoritarian state is not necessarily a caring state.

Second, our analysis of NPO networking behaviour was based on the theory of network governance posed by Jones and her colleagues. We showed that all German and Chinese NPOs in our sample used networking to overcome the difficulties in their working environments characterised mainly by asset specificity, funding uncertainty, and task complexity. We identified four types of networking, namely NPOs that are themselves organised as networks (sometimes at the request of the local government such as Chance+ and Bridge), stakeholder networks, networks excluding government agents, and networks in which the state plays a dominant role. Given the authoritarian political system of China our data demonstrated that many (but not all!) of the Chinese NPOs in our sample were embedded in a network with a dominant role played by the local government. At the same time, almost all German and Chinese NPOs decided to include government actors in their networks which helps ensure congruence of general concepts on how to solve the social issues at hand. Outsourcing and networking are similar strategies of local governments and NPOs in China and Germany - despite all the obvious differences. Although the state clearly plays a more dominant role in authoritarian China, we were able to show that local states and societal actors in both China and Germany can choose among diverse - rather than uniform - strategies to tackle pressing social issues. 


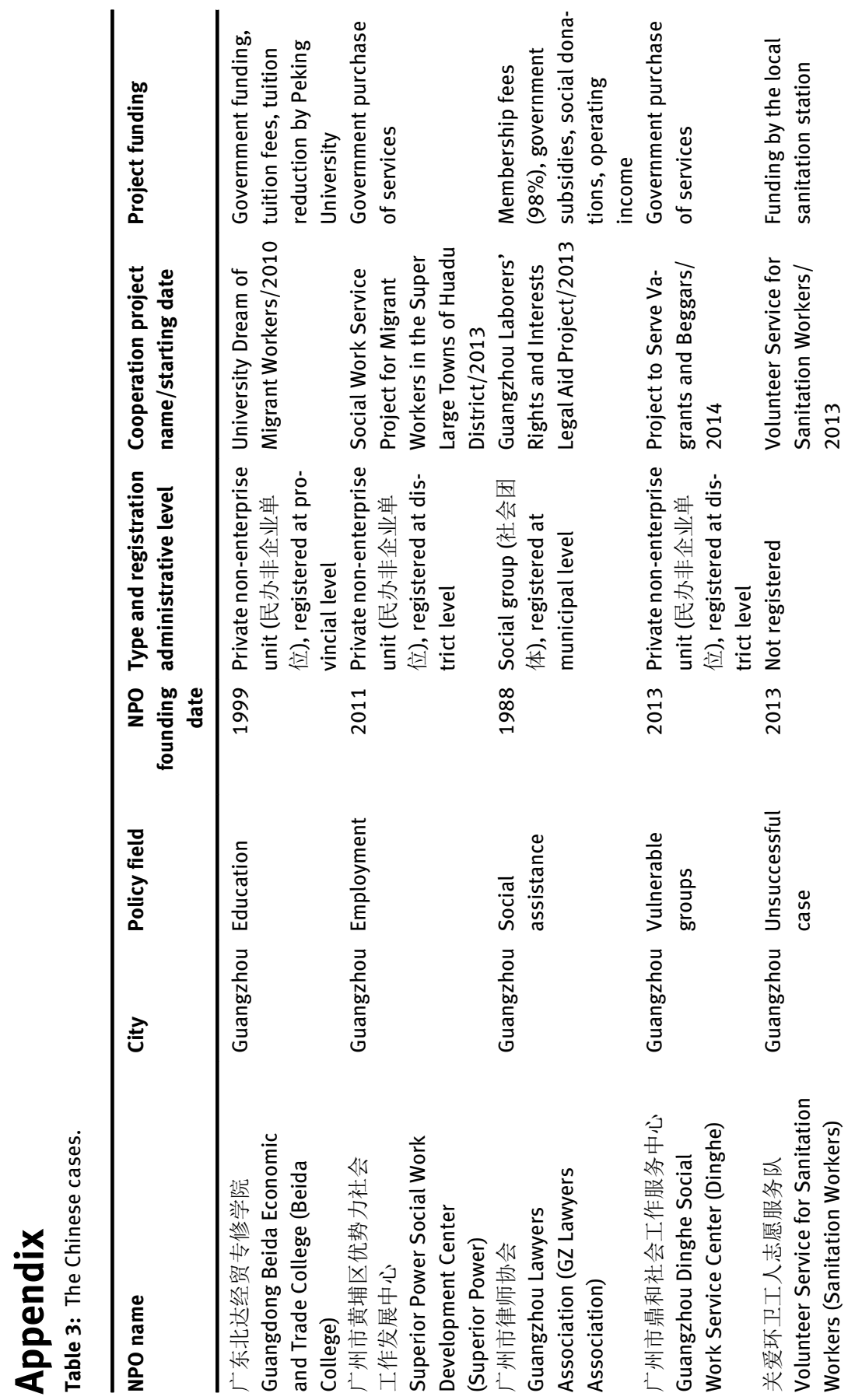




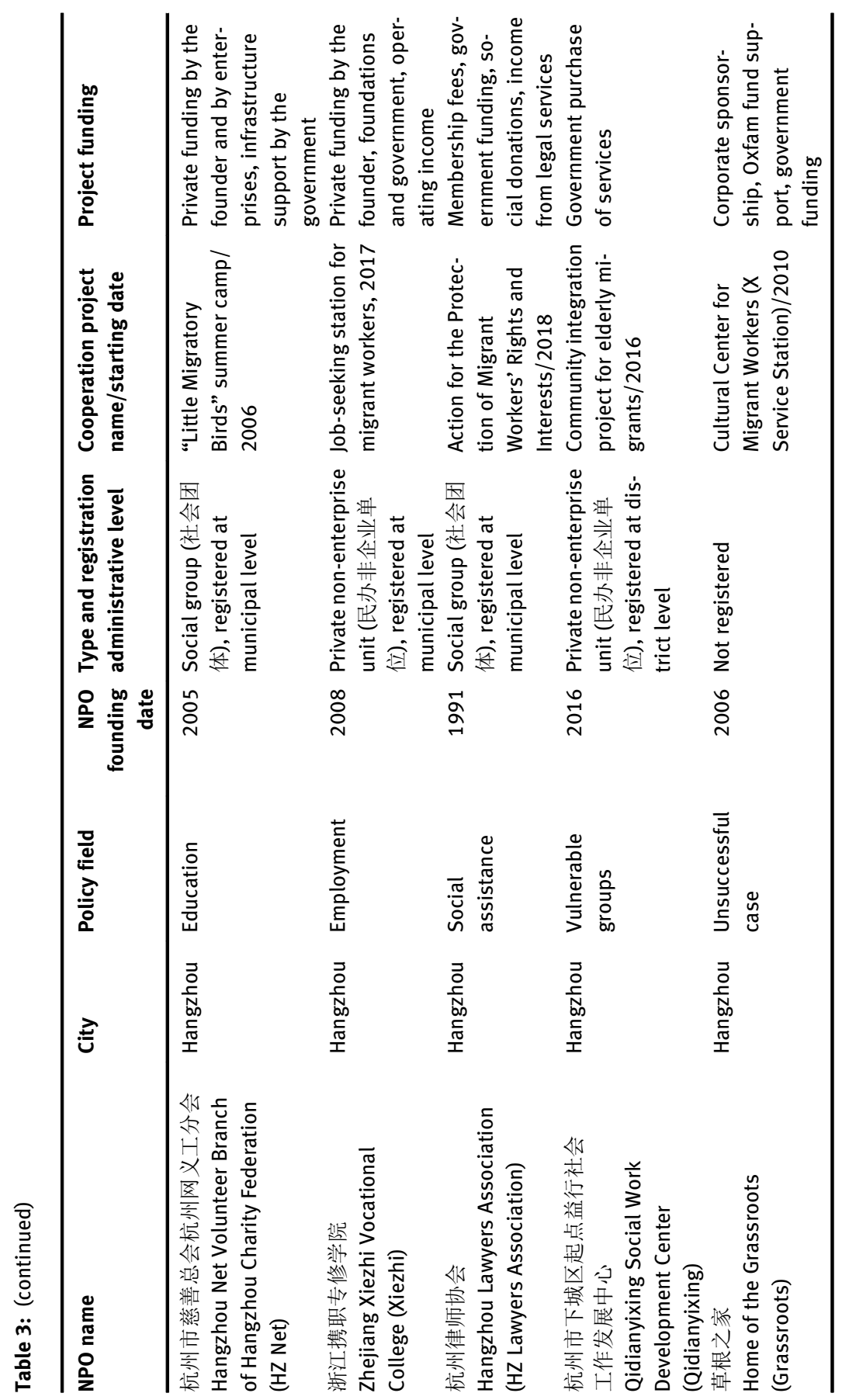




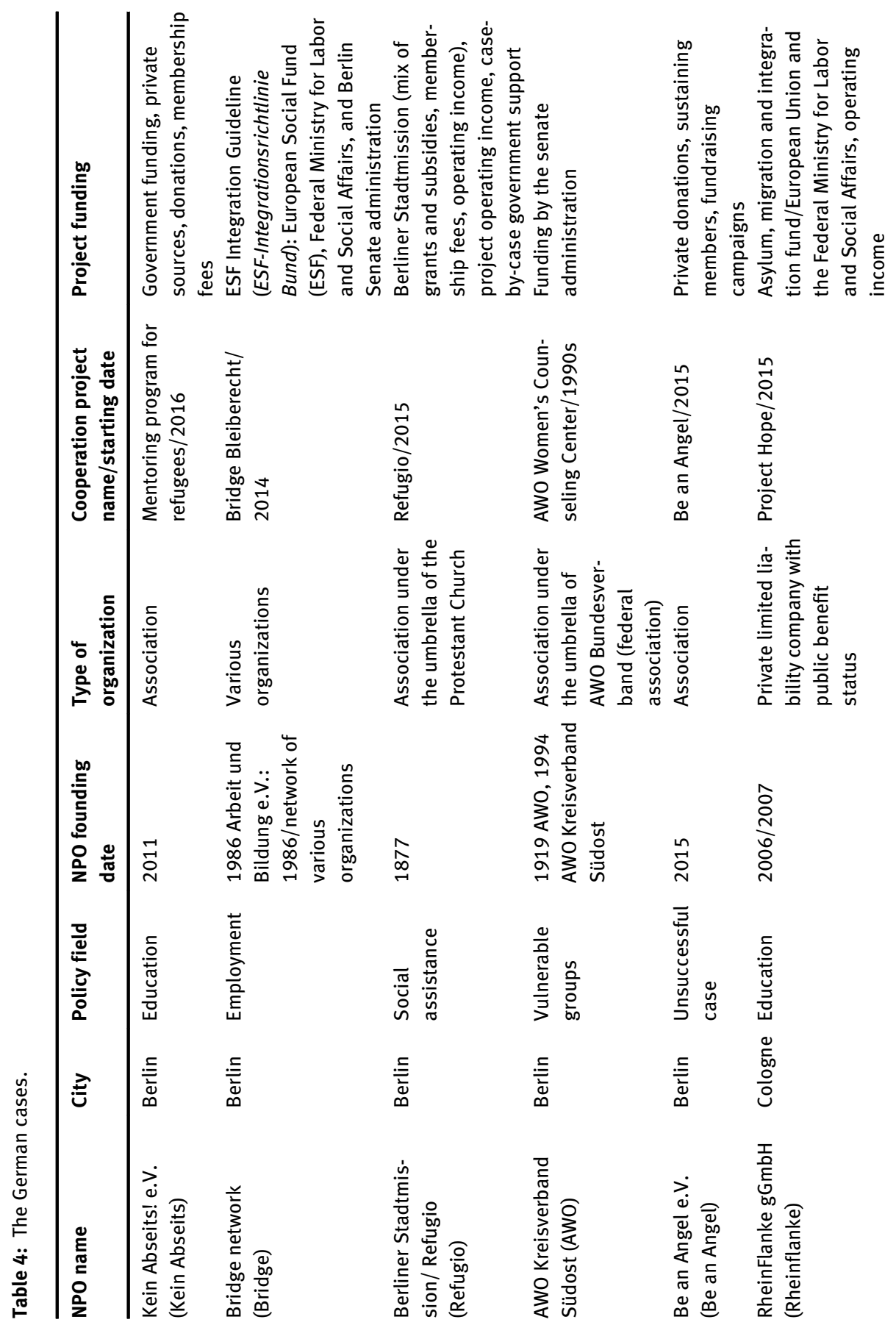




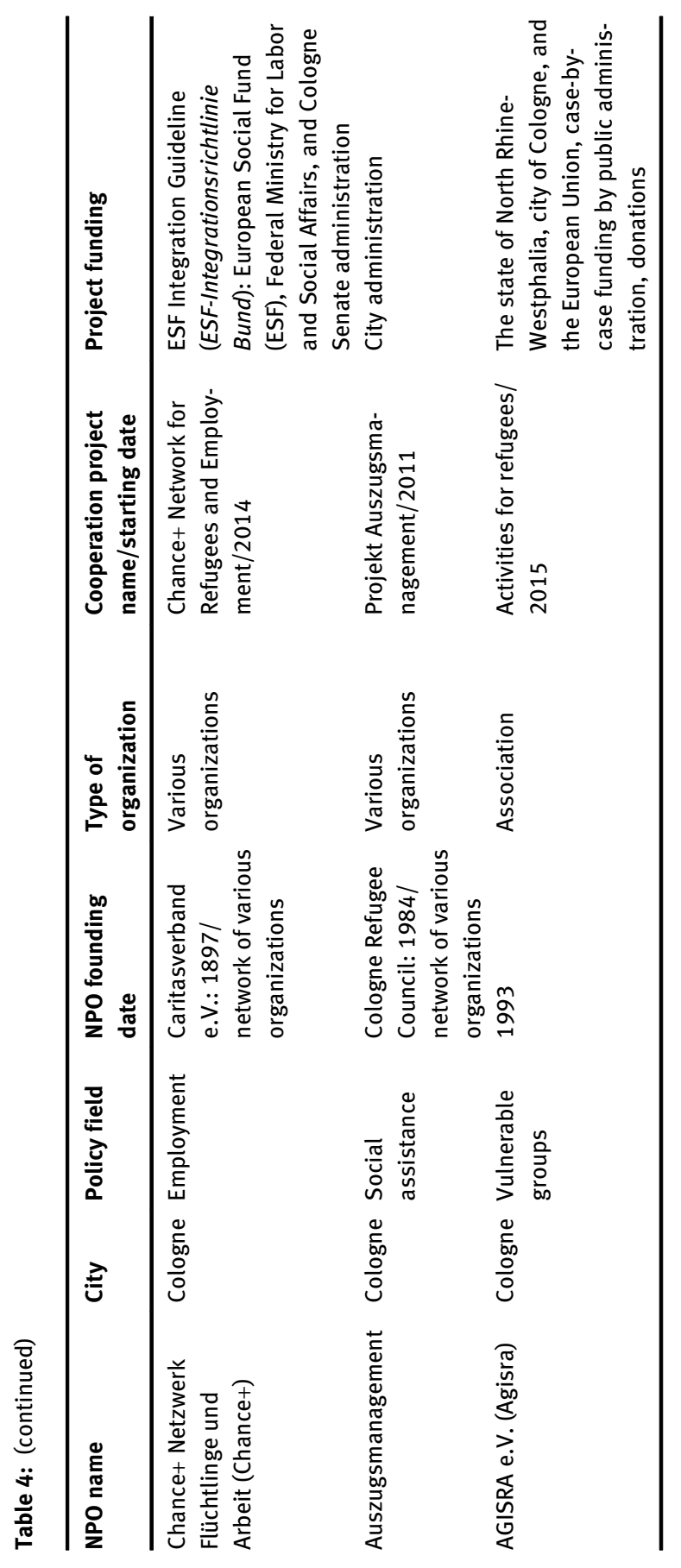




\section{References}

Altrock, U., and R Kunze. 2016. Stadterneuerung und Armut. Jahrbuch Stadterneuerung 2016. Wiesbaden: Springer VS.

Bevir, M. 2012. Governance: A Very Short Introduction. Oxford: Oxford University Press.

Cai, Y., and Z. Liu. 2015. "Poverty and Health: Children of Rural-To-Urban Migrant Workers in Beijing, China." Social Indicators Research 123 (2): 459-77.

Coston, J. M. 1998. “A Model and Typology of Government-NGO Relationships.” Nonprofit and Voluntary Sector Quarterly 27 (3): 358-82.

Emerson, K., and T. Nabatchi. 2015. Collaborative Governance Regimes. Washington, DC: Georgetown University Press.

Evers, A. 2011. "Wohlfahrtsmix im Bereich sozialer Dienste." In Handbuch Soziale Dienste, edited by A. Evers, R. G. Heinze, and T. Olk, 265-83. Wiesbaden: VS Verlag für Sozialwissenschaften.

Freise, M., and A. Zimmer. 2019a. "Zivilgesellschaft und Wohlfahrtsstaat in Deutschland: Eine Einführung." In Zivilgesellschaft und Wohlfahrtsstaat im Wandel. Akteure, Strategien und Politikfelder, edited by M. Freise, and A. Zimmer, 3-5. Wiesbaden: VS Verlag für Sozialwissenschaften.

Freise, M., and A. Zimmer. 2019b. "Zivilgesellschaft und Wohlfahrtsstaat in Deutschland: Ein kurzer Ausblick." In Zivilgesellschaft und Wohlfahrtsstaat im Wandel. Akteure, Strategien und Politikfelder, edited by M. Freise, and A. Zimmer, 395-402. Wiesbaden: VS Verlag für Sozialwissenschaften.

Granovetter, M. S. 1992. "Problems of Explanation in Economic Sociology." In Networks and Organizations: Structure, Form, and Action, edited by N. Nohria, and R. G Eccles, 25-56. Boston: Harvard Business School Press.

Hasmath, R., and J. Y. J Hsu. 2015. NGO Governance and Management in China, London and New York: Routledge.

Hildebrandt, T. 2013. Social Organizations and the Authoritarian State in China. Cambridge and Others: Cambridge University Press.

Hood, C. 1991. “A Public Management for All Seasons.” Public Administration 69 (1): 3-19. Jing, Y. 2015. "Between Control and Empowerment: Governmental Strategies Towards the Development of the Non-profit Sector in China." Asian Studies Review 39 (4): 589-608.

Jones, C., S. W. Hesterly, and S. P. Borgatti. 1997. "A General Theory of Network Governance: Exchange Conditions and Social Mechanisms." Academy of Management Review 22 (4): 911-45.

Kang, X. 康晓光, and H. Heng 韩恒. 2005. “分类控制: 当代中国大陆国家与社会关系研 [The System of Differential Controls: A Study of the State-Society Relation in Contemporary China].” 社会学研究 [Sociological Studies] 20 (6): 73-89.

Kang, X., and H. Heng. 2008. "The State-Society Relationship in Contemporary China.” Modern China 34 (1): 36-55.

Kapucu, N., and Q. Hu. 2020. Network Governance. Concepts, Theories, and Applications. New York and London: Routledge.

Ketels, A. 2019. "Migrant Integration as a Challenge for Local Governments and Social Organizations in China and Germany - Policy Traditions and Integration Measures in Guangzhou, Hangzhou, Berlin and Cologne." LoGoSO Research Papers Nr 8. Also available at https://refubium.fu-berlin.de/handle/fub188/24154. 
Levy, K. 2020. "Local Public Administration and Social Policy in Germany and China." LoGoSO Research Papers Nr 5. Also available at https://refubium.fu-berlin.de/handle/fub188/ 17676.

Levy, K., and K. B. Pissler. 2020. Charity with Chinese Characteristics. Chinese Charitable Foundations between the Party-State and Society. Cheltenham: Edward Elgar.

Ma, Q., Fan, J., and M. Shan. 2017. Reform and Development of the Regional Public Administration System in China. LoGoSO Internal Report (unpublished).

Ma, Q. 马庆钰, and H. Liao 廖鸿. 2015. 中国社会组织发展战略 [National Strategy of Promoting the Development of China's Social Organizations]. Beijing: Social Sciences Academic Press.

Najam, A. 2000. “The Four-C's of Third Sector-Government Relations. Cooperation, Confrontation, Complementarity, and Co-optation." Nonprofit Management and Leadership 10 (4): 375-96.

Salamon, L. 1987. "Of Market Failure, Voluntary Failure, and Third-Party Government: Toward a Theory of Government-Nonprofit Relations in the Modern Welfare State." Nonprofit and Voluntary Sector Quarterly 16: 1-2. 29-49.

Salamon, L. 1995. Partners in Public Service. Government-Nonprofit Relations in the Modern Welfare State. Baltimore and London: The Johns Hopkins University Press.

Salamon, L. 2011. "The New Governance and the Tools of Public Action: An Introduction.” Fordham Urban Law Journal 28 (5): 1611-74.

Salamon, L. M., and S. Toepler. 2015. "Government-Nonprofit Cooperation. Anomaly or Necessity?" Voluntas 26: 2155-77.

Schmitter, P. C. 1974. "Still the Century of Corporatism?" Review of Politics 36 (1): 85-131.

Szeili, J. and Zimmer, A. 2017. Local Public Administration and Governance in Comparative Perspective. LoGoSO Internal Report (unpublished).

Teets, J. 2014. Civil Society under Authoritarianism. The China Model. New York: Cambridge University Press.

Unger, J., and A. Chan. 1995. "China, Corporatism, and the East Asian Model." The Australian Journal of Chinese Affairs, 33 (January): 29-53.

Wang, Q., and X. Kang. 2018. “China's Nonprofit Policymaking in the New Millennium.” Nonprofit Policy Forum 9 (1): 1-4.

Wang, W., and H. Snape. 2018. "Government Service Purchasing from Social Organizations in China: An Overview of the Development of a Powerful Trend.” Nonprofit Policy Forum 9 (1), https://doi.org/10.1515/npf-2017-0032.

Young, D. R. 2000. "Alternative Models of Government-Nonprofit Sector Relations: Theoretical and International Perspectives." Nonprofit and Voluntary Sector Quarterly 29 (1): 149-72.

Zimmer, A. 2010. "Third Sector-Government Partnerships." In Third Sector Research, edited by R. Taylor, 201-18. New York: Springer.

This research project was made possible by the generous funding of Stiftung Mercator (Project No. 1533200). 